\title{
Detection of serum antibodies against Leptospira spp. in brown rats (Rattus norvegicus) from Grenada, West Indies
}

\author{
Ravindra Nath Sharma, Katelyn Thille, Brianna Piechowski and Keshaw Tiwari \\ Department of Pathobiology, School of Veterinary Medicine, St. George's University, Grenada, West Indies. \\ Corresponding author: Ravindra Nath Sharma, e-mail: rsharma@sgu.edu \\ Co-authors: KaT: kthille@sgu.edu, BP: bpiechow@sgu.edu, KeT: tiwarik.73@gmail.com \\ Received: 18-12-2018, Accepted: 25-03-2019, Published online: 23-05-2019
}

doi: 10.14202/vetworld.2019.696-699 How to cite this article: Sharma RN, Thille K, Piechowski B, Tiwari K (2019) Detection of serum antibodies against Leptospira spp. in brown rats (Rattus norvegicus) from Grenada, West Indies, Veterinary World, 12(5): 696-699.

\begin{abstract}
Background and Aim: Leptospirosis is an emerging disease of animals and humans. Among rodents brown rats (Rattus norvegicus) are an important reservoir of bacteria Leptospira. There is a paucity of information on reservoirs of Leptospira in Grenada. This study was conducted to estimate the prevalence of antibodies against Leptospira spp. in brown rats in a densely human populated area of Grenada.
\end{abstract}

Materials and Methods: Blood samples from 169 brown rats were collected and sera screened for antibodies against Leptospira spp. using enzyme-linked immunosorbent assay.

Results: Among a total of 169 brown rats trapped in two parishes in Grenada, 77/169 (45.5\%) were positive for Leptospira spp. antibodies. A significant difference in seropositive population of brown rats between two collection sites was observed. No differences were found between sex and age of seropositive rats.

Conclusion: Due to the close contact of brown rats with humans in Grenada, rats should be considered a high-risk factor in transmission of Leptospira to humans. Appropriate preventive measures should be instituted to prevent the transmission of Leptospira infection to humans.

Keywords: brown rats, enzyme-linked immunosorbent assay, Grenada, Leptospira spp.

\section{Introduction}

Leptospirosis is an emerging zoonosis in the world. Leptospirosis is caused by spirochetes of the genus Leptospira [1]. Leptospira spp. include pathogenic and non-pathogenic bacteria. Pathogenic Leptospira include eight species divided into 250 serotypes and 24 serogroups [2]. Leptospirosis is a disease of humans and animals. Humans can get infected from animal reservoirs. Among animals, rodents are important reservoirs of Leptospira $[3,4]$.

Brown rats (Rattus norvegicus) are considered major natural reservoir of leptospirosis $[5,6]$. The most usual route of transmission is close contact with urine, within animal groups as well as humans. Mucosae (nose and eyes) and skin abrasions in contact with infected urine are the usual routes of infection. Occasional route of transmission is by ingestion of water and food contaminated with urine or tissues of infected animals. Bacteria entering the body circulate and finally localize in the kidneys. Leptospira colonizes in the proximal convoluted tubules of the kidney [7]. Monahan et al. [8] reported that persistent colonization

Copyright: Sharma, et al. Open Access. This article is distributed under the terms of the Creative Commons Attribution 4.0 International License (http://creativecommons.org/licenses/ by/4.0/), which permits unrestricted use, distribution, and reproduction in any medium, provided you give appropriate credit to the original author(s) and the source, provide a link to the Creative Commons license, and indicate if changes were made. The Creative Commons Public Domain Dedication waiver (http:// creativecommons.org/publicdomain/zero/1.0/) applies to the data made available in this article, unless otherwise stated. in kidneys is due to immune privileged tissue of the kidneys. Chronically infected rats are asymptomatic, but they excrete Leptospira in the urine [9].

Leptospirosis has been reported from countries of South America and the Caribbean [10]. There are limited studies on leptospirosis in Grenada. Leptospirosis has been reported in cattle, pigs, sheep, goat, dogs, and chickens in Grenada [11-13]. With the exception of Keenan et al. [14] report, no published research is available on leptospirosis in brown rats from Grenada.

The aim of the current research was to estimate the serum antibodies against Leptospira spp. in brown rats from Grenada.

\section{Materials and Methods \\ Ethical approval}

The project (detection of zoonotic pathogens in brown rats ( $R$. norvegicus) in Grenada) was approved by the Institutional Animal Care and Use Committee (IACUC ${ }^{*} 16009-R$ ) of the St. George's University, Grenada.

\section{Study area}

Grenada is the southernmost country in the Caribbean Sea with an area of $348.5 \mathrm{~km}^{2}$. The country with low hills, small trees, shrubs, and tropical climate is most suitable for rats. The country is comprised of six parishes: St. Patrick, St. Mark, St. Andrew, St. John, St. George, and St. David. St. David and St. George parishes, which have a higher human population compared to the other four parishes, were selected for the study. 


\section{Collection of rats}

A total of 169 rats were collected live from May 1 to July 14, 2017, using traps $(45 \mathrm{~cm} 1 \times 15 \mathrm{~cm}$ $\mathrm{w} \times 15 \mathrm{~cm} \mathrm{~h}$ ) with cheese and various local fruits as bait. Attempts were made to trap the rats from and near the residential buildings. Traps were placed 2 days/week in the evening and visited the morning of the next day. Traps with rats were covered with black cloth and transported to the necropsy laboratory of St. George's University, School of Veterinary Medicine. Rats were anesthetized using 1-2\% isoflurane in oxygen through portable vet anesthesia machine isoflurane vaporizer VET CE, manufacturer DRE (Avante Health Solutions Company, USA)

\section{Collection of samples and testing}

The anesthetized rats were examined for their physical health and weighed. Gender was also recorded. Rats below $100 \mathrm{~g}$ were grouped as young and those over $100 \mathrm{~g}$ as adult, following the methodology used by Panti-May et al. [15]. Blood was collected from the heart through the thoracic wall and rats were exsanguinated this way. Sera were separated from the blood by centrifugation at $1500 \mathrm{~g}$ for $15 \mathrm{~min}$ at room temperature and stored at $-80^{\circ} \mathrm{C}$ until tested. Enzyme-linked immunosorbent assay (ELISA) test for Leptospira antibodies on sera was performed using rat Leptospira IgG ELISA kit from MyBioSource, Inc., San Diego, CA 92195-3308 USA. The antigen in the ELISA kit was whole Leptospira biflexa organisms.

\section{Statistical analysis}

Data were analyzed using a Chi-squared analysis and stratified by gender, age, and parish of rats in Microsoft Excel 2017 software. Statistical significance was set at $\mathrm{p}=0.05$.

\section{Results}

Antibodies to Leptospira spp. were found in $77 / 169(45.5 \%)$ rats of 169 tested. St. George parish had a higher number of positive rats $43 / 76(56.5 \%)$ compared to St. David, where 34/93 (36.5\%) rats were seropositive. Male and female and young and adult rats had equal prevalence of antibodies (male $45.9 \%$ and female 43.9\%; young 42.1\% and adults $46.0 \%$ ). There was no statistical significance between gender and age. The serological results of ELISA according to parish, gender, and age are presented in Table 1.

\section{Discussion}

Diagnosis for leptospirosis is usually performed by serology: ELISA or microscopic agglutination tests (MAT) [4]. Serology is not useful in acute disease as antibodies develop in later stages of the disease. In recent years, PCR techniques have been used for the diagnosis of leptospirosis [4]. The detection of leptospires in tissue samples is based on culture, staining, and immunofluorescence techniques [7].

Previous researchers have reported variation in seropositivity of Leptospira in rats in different countries. Koma et al. [16] reported a 22\% prevalence of
anti-Leptospira antibodies by ELISA in $R$. norvegicus in Northern Vietnam. In 2010, a survey for anti-Leptospira antibodies in $R$. norvegicus in Brazil revealed 63\% of rats seropositive [17]. They used immunofluorescence on kidney smears to identify Leptospira. An earlier study in Brazil [5] reported $68.1 \%$ positive $R$. norvegicus for Leptospira antibodies diagnosed by MAT. Sharon et al. [18] found $92 \%$ of rat serum samples positive for anti-Leptospira antibodies in the Philippines by MAT. Norway rats in Maryland, USA, were found positive (65.3\%) for anti-Leptospira antibodies [19] diagnosed by ELISA. In Caribbean nations, including Grenada, studies on Leptospira were confined to livestock and humans; however, in Grenada, only one study made by Keenan et al. [14] reported the seroprevalence of Leptospira in $R$. norvegicus. They identified $24.5 \%$ of rats positive for Leptospira antibodies by ELISA and $7.1 \%$ positive by MAT. Compared to the previous study [14] in Grenada, this study found higher seropositivity (45.5\%) in R. norvegicus for Leptospira antibodies by ELISA. The prevalence of antibodies for Leptospira spp. ranged from $22 \%$ to $92 \%$ in different countries. The variation in the prevalence of antibodies against Leptospira in different geographical location may be due to changes in climate and environmental conditions [20].

Comparison of the prevalence of antibodies in different studies is also complicated by sample size and laboratory methods [21]. The antibody estimation in serological diagnosis is dependent on the Leptospira spp. antigen present in ELISA kit. The antigen component of ELISA differs from one to another ELISA kit; however, in most products, the nature of antigen is not described. Most kits use crude whole cell lysate as antigens [22]. Same authors [22] evaluated the diagnostic utility of recombinant antigens, which contain portions of genes encoding the leptospiral outer membrane protein (LipL32, Ompl1, LipL36, LipL41, and Hsp58) in serodiagnosis of leptospirosis. Researchers recommended LipL32 had the highest sensitivities in the acute and convalescent phages of the leptospirosis. Other recombinant antigens gave insignificant reaction. In the present study, we used ELISA which contained whole $L$. biflexa organism. Since the details of $L$. biflexa organism are not available, it would be inappropriate to compare our serological results with previous researchers using different antigens.

In the present study, statistically significant differences in the prevalence of antibodies for Leptospira in brown rats were found between St. George and St. David parish. The climatic and environmental conditions being the same in both parishes, the difference is not fully understood. Future research involving a higher number of rats from all six parishes of the country may be more insightful regarding the distribution of antibodies of Leptospira in rat population of Grenada.

In the present study, no significant differences were found in the prevalence of antibodies 
between young and adult rats which are in accordance with Suepaul et al. [23] for many species of animals, except rats where juvenile were more susceptible. Contrary to our finding; the previous researchers $[24,25,26]$ observed higher prevalence in older rats.

There was no difference in antibody prevalence between male and female rats. This finding is in concurrence with the previous researcher [27], whereas Easterbrook et al. [19] reported a higher prevalence of antibodies in female rats in the USA. In human patients from 14 Caribbean countries, males had a higher frequency of seropositivity compared to females. [28]. The difference between genders is not well explained since both sexes are equally exposed to Leptospira infection.

\section{Conclusion}

The high prevalence of antibodies found in brown rats for Leptospira spp. in Grenada should be of great concern. In Grenada, cases of Leptospira infections in humans have been reported [28]. Due to the close contact of brown rats with humans in Grenada, rats should be considered a high-risk factor in transmission of Leptospira to humans. Preventive measures should be directed toward minimizing the exposure of rats with humans and possible reduction in Grenada's rat population.

\section{Authors' Contributions}

RNS planned and supervised the research and manuscript writing; KeT trapping of rats, collection of blood, helping in ELISA, statistical analysis of results, and review of the manuscript; KaT performed ELISA and edited manuscript; BP collection of blood, and performance of ELISA. All authors read and approved the final manuscript.

\section{Acknowledgments}

The authors appreciate the financial support from the St. George University, Grenada, through a grant "One Health research Initiative" (OHRI 06-14-10).

\section{Competing Interests} interests.

The authors declare that they have no competing

\section{Publisher's Note}

Veterinary World remains neutral with regard to jurisdictional claims in published institutional affiliation.

\section{References}

1. Guerra, M.A. (2009) Leptospirosis. J. Am. Vet. Med. Assoc., 234(4): 472-478.

2. Dutta, T.K. and Christopher, M. (2005) Leptospirosis-an over-view. J. Assoc. Physicians India, 53(6): 545-551.

3. Desvars, A., Naze, F., Voure'h, G., Cardinale, E., Picordeau, M., Michault, A. and Bourhy, P. (2012) Similarities in Leptospira serogroups and species distribution in animals and humans in the Indian Ocean island of
Mayotte. Am. J. Trop. Med. Hyg., 87(1): 134-140.

4. Musso, D. and Scola, B.L. (2013) Laboratory diagnosis of leptospirosis: A challenge. J. Microbiol Immunol. Infect., 46(4): 245-252.

5. De Faria, M.T., Calterwood, M.S., Athanazio, D.A., McBride, A.J., Hartskeeri, R.A., Pereira, M.M., Ko, A.L. and Reis, M.G. (2008) Carriage of Leptospira interrogans among domestic rats from an urban setting highly endemic for leptospirosis in Brazil. Acta Trop., 108(1): 1-5.

6. Amelia, N.S.A., Claudio, P.F., Mitermayer, G.D.R., Federico, C. and Ristow, P. (2015) Heterogenic colonization patterns by Leptospira interrogans in Rattus norvegicus from urban slums. Braz. J. Microbiol., 46(4): 1161-1164.

7. Athanazio, D.A., Silva, E.F., Santos, C.S., Rocha, G.M., Vannier-Santos, M.A., McBride, A.J., Ko, A.I. and Reis, M.G. (2008) Rattus norvegicus as a model for persistent renal colonization by pathogenic Leptospira interrogans. Acta Trop., 105(2): 176-180.

8. Monahan, A.M., Callanan, J.J. and Nally, J.E. (2009) Review paper: Host-pathogen interactions in the kidney during chronic leptospirosis. Vet. Pathol., 46(5): 792-799.

9. Da Silva Zacarias, F.G., Vasconcellos, S.A., Anzai, E.K., Giraldi, N., de Freitas, J.C. and Hartseerl, R. (2008) Isolation of Leptospira serovars canicola and copenhageni from cattle urine in the state of Panama, Brazil. Braz. J. Micobiol., 39: 744-748.

10. Pappas, G., Papadimitriou, P., Siozopopulou, V., Chritou, L. and Akritidis N. (2008) The globalization of leptospirosis: Worldwide incidence trends. Int. J. Infect. Dis., 12(4): 351-357.

11. Everard, C.O., Fraser-Chanpong, G.M., James, A.C. and Butcher, L.V. (1985) Serological studies on leptospirosis in livestock and chickens from Grenada and Trinidad. Trans. R. Soc. Trop. Med. Hyg., 79(6): 859-864.

12. Emily, C., Jill, C., Marquita, V., Hilaire, G.S., Omowale, A.M., Harold, L.R., Sharma, R.N. and Stone, D.M. (2008) Seroprevalence of Leptospira in dogs in Grenada, West Indies. West Indian Vet. J., 8(2): 50-55.

13. Elan, A., Tiwari, K., Christine, B., Benjamin, J., Josephine, T. and Sharma, R.N. (2018) Prevalence of antibodies against Leptospira spp. In pigs from Grenada, West Indies. Int. J. Livest. Res., 8(8): 62-66.

14. Keenan, J., Sharma, R., Dicker, R., Rayner, J. and Stone, D. (2009) Seroprevalence of Leptospira in Rattus norvegicus in Grenada, West Indies. West Indian Med. J., 58(2): 114-117.

15. Panti-May, J.A., Hernadez-Betancourt, S., Ruiz-Pina, H. and Medina-Peralta, S. (2012) Abundance and population parameters of commensal rodents present in rural household in Yucatan, Mexico. Int. Biodeterior. Biodegradation, 66(1): 77-81.

16. Koma, T., Yosimatsu, K., Yasuda, S.P., Li, T., Amada, T., Shimizu, K., Isozumi, R., Mai, L.T., Hoa, N.T., Nguyen, V., Yamashiro, T., Hasebe, F. and Arikawa, J. (2013) A survey of rodent-borne pathogens carried by wild Rattus spp. In Northern Vietnam. Epidemiol. Infect., 141(9): 1876-1884.

17. Costa, F., Porter, F.H., Rodrigues, G., Farias, H., de Faria, M.T., Wunder E.A., Osikowicz, L.M., Kosoy, M.Y., Reis, M.G., Ko, A.I. and Childs, J.E. (2014) Infections by Leptospira interrogans, seoul virus, and Bartonella spp. Among Norway rats ( $R$. norvegicua) from the urban slum environment in Brazil. Vector Borne Zoonotic Dis., 14(1): 33-40.

18. Sharon, Y.A.M., Hirokazu, E., Baterna, R.A., Yasutake, Y., Maki, M., Nobuo, K., Takashi, F., Yoshihiro, O., Toshiyuki, M., Lolita, L., Cavinta, N.G. and Shin-Ichi, Y. (2010) Serologic and molecular studies of leptospirosis among rats in the Philippines. Am. J. Trop. Med. Hyg., 82(5): 889-898.

19. Easterbrook, J.D., Kaplan, J.B., Vanasco, N.B., Reeves, W.K., Purcell, R.H., Kosoy, M.Y., Glass, G.E., Watson, J. and Klein, S.L. (2007) A survey of zoonotic pathogens carried by Norway rats in Baltimore, Maryland, 
USA. Epidemiol. Infect., 135(7): 1192-1199.

20. Pratt, N. and Rajeev, S. (2018) Leptospira seroprevalence in animals in the Caribbean region: A systematic review. Acta Trop., 182: 34-42.

21. Webster, J.P., Ellis, W.A. and Macdonald, D.W. (1995) Prevalence of Leptospira spp. In wild brown rats (R. norvegicus) on UK farms. Epidemiol. Infect., 114(1): 195-201.

22. Flannery, B., Costa, D., Carvalho, F.P., Guerreiro, H., Matsunaga, J., Da Silva, E.D., Ferreira, A.G.P., Riley, L.W., Reis, M.G., Haake, D.A. and Ko, A.I. (2001) Evaluation of recombinant Leptospira antigen-based enzyme-linked immunosorbent assays for the serodiagnosis of leptospirosis. J. Clin. Microbiol., 39(9): 3303-3310.

23. Suepaul, S.M., Carrington, C.V., Campbell, M., Borde, G. and Adesiyun, A.A. (2014) Seroepidemiology of leptospirosis in dogs and rats in Trinidad. Trop. Biomed., 31(4): 853-861.

24. Ivanova, S., Herbreteau, V., Blasdell, K., Chaval, Y., Buchy, P., Guillard, B. and Morand, S. (2012) Leptospira and rodents in
Cambodia: Environmental determination of infection. Am. J. Trop. Med. Hyg., 86(6): 1032-1038.

25. Wang, C. and He, H. (2013) Leptospira spp. In commercial rodents, Beijing, China. J. Wildl. Dis., 49(2): 461-463.

26. Hoang, K.L., Nguyen, V.C., Ratree, T., Bach, T.K., James, K., Lac, N.T., Juliet, E.B., Bousaraporn, T., Nguyen, V.H., Serge, M., Vo, B.H. and Juan, J.C.M. (2015) How important are rats as vectors of leptospirosis in Mekong Delta of Vietnam. Vector Borne Zoonotic Dis., 15(1): 56-64.

27. Krojgaard, L.H., Villumsen, S., Markussen, M.D., Jensen, J.S. and Heiberg, A.C. (2009) High prevalence of Leptospira spp. In sewer rats (R. norvegicus). Epidemiol. Infect., 137(11): 1586-1592.

28. Adesiyun, A.A., Baboolal, S., Suepal, S., Dookaren, S. and Johnson, A.S. (2011) Human leptospirosis in the Caribbean, 1997-2005: Characteristics and serotyping of clinical samples from 14 countries. Rev. Panam. Salud Publica., 29: 350-357. 